\title{
Antioxidant, total phenolic contents and antinociceptive potential of Teucrium stocksianum methanolic extract in different animal models
}

\author{
Syed Muhammad Mukarram Shah ${ }^{1}$, Abdul Sadiq ${ }^{1 *}$, Syed Muhammad Hassan Shah² and Farhat Ullah ${ }^{1}$
}

\begin{abstract}
Background: Oxidative stress and analgesia are connected with different pathological conditions. The drug candidates from synthetic sources are associated with various side effects; therefore, researchers are giving priority to find novel, effective and safe phytomedicines. Teucrium species possesses antioxidant, analgesic, anti-inflammatory and hepatoprotective activities. The essential oils of Teucrium stocksianum have shown strong antinociceptive potential. Our current study is designed to embark total phenolic content (TPC), antioxidant and antinociceptive potential of the methanolic extract of Teucrium stocksianum (METS).
\end{abstract}

Method: Phytochemical composition was determined by using standard methods. Free radical scavenging potential and TPC of METS were assessed by using 2, 2-diphenyl-1-picryl-hydrazyl (DPPH) and Folin-Ciocalteu Reagent (FCR) respectively. Antinociceptive potential was determined by acetic acid induced abdominal writhing, formalin induced paw licking and tail immersion tests. Different test dose 50, 100 and $150 \mathrm{mg} / \mathrm{kg}$ body weight of METS were administered intra peritonealy (i.p) to various groups of mice for the evaluation of analgesic potential.

Results: Phytochemical screening confirmed the presence of flavonoids, tannins, saponins, anthraquinone, steroid, phlobatannin, terpenoid, glycoside and reducing sugars. METS was found safe at a dose of $1000 \mathrm{mg} / \mathrm{kg}$ body weight. A concentration dependent free radical scavenging effect was observed with methanolic aerial parts extract of Teucrium stocksianum (MAPETS) and methanolic roots extracts of Teucrium stocksianum (MRETS). MAPETS and MRETS have shown highest antioxidant activity $91.72 \%$ and $86.19 \%$ respectively at $100 \mu \mathrm{g} / \mathrm{ml}$. MAPETS was found more rich (115.32 mg of GAE/g of dry material) in TPC as compared to MAPETS (105.41 mg of GAE/g). METS demonstrated a dose dependent antinociceptive potential in different pain models, like in acetic acid, formalin and tail immersion showing $83.103 \%, 80.872 \%$ and $67.58 \%$ at a dose of $150 \mathrm{mg} / \mathrm{kg}$, similar to acetylsalicylic acid $(74.79 \%, 82.87 \%, 100 \mathrm{mg} / \mathrm{kg})$ and Tramadol $^{R}(74 \%, 30 \mathrm{mg} / \mathrm{kg})$ respectively.

Conclusion: Strong antioxidant potential and high TPCs are residing in the methanolic extract of T. stocksianum. METS showed analgesic potential in all models of nociception implying that both peripheral and central pathways of analgesia are involved. This might be due to the presence of various classes of phytochemicals in the plant extract.

Keywords: Teucrium stocksianum, Antioxidant, Total phenolic contents, Analgesic

\footnotetext{
* Correspondence: sadiquom@yahoo.com

'Department of Pharmacy, University of Malakand, Chakdara Dir, KPK,

Paksitan

Full list of author information is available at the end of the article
} 


\section{Background}

The use of plants in curing various diseases is a reexplored field for the new research. Plants not only providing environmental survival to human beings but are also playing a vital role in the management of various diseases.

Medicinal plants synthesize secondary metabolites which are rich and novel sources of traditional and modern system of medicines. Herbal and natural products have a long known history in folk medicines. These products are safer, economical and can be used as parallel alternative to the modern synthetic drugs. The published literature available on medicinal plants has shown that phytochemicals can be used for the management of health problems like diabetes, cancer and infectious diseases [1,2].

Free radicals e.g. Reactive Oxygen Species (ROS) are toxic to the body when generated in high amounts as a result of oxidative stress. Although low levels of ROS are necessary for cells to carry out normal biochemical functions like cell signaling, apoptosis of defective cells etc. They are extremely reactive and at high levels during oxidative stress they may damage proteins, lipids and DNA molecules, which are responsible for various diseases like diabetes, cancer, Alzheimer's and cardiovascular disease. Compounds obtained from natural sources can prevent toxic effects of the free radicals [3,4]. Medicinal plants possess antioxidant potential and can efficiently combat the free radicals produced inside the cell [5].

According to the International Association for the Study of Pain, it is, "an unpleasant sensory and emotional experience associated with actual or potential tissue damage, or described in terms of such damage" [6]. Plants have been used as antinociceptive agents since the pre-historic era. Currently, nonsteridal anti-inflammatory drugs (NSAIDs) and narcotics are the most prominent classes of pain killers. But there is marked risk of some serious side effects like renal, hepatic and gastrointestinal complications with the use of NSAIDs. While constipation and drug dependence issues are associated with narcotic analgesics $[7,8]$.

Labiatae (Lamiaceae) is one of the largest families of flowering plants with about 220 genera and almost 4000 species worldwide [9]. Because of extensive species diversity and endemism in Labiatae some species are used in traditional medicine in Iran [10]. It has been reported that Teucrium species possesses antiseizure [11], antioxidant [12], acetylcholine easterase, butaryl choline esterease inhibition [13] and hepatoprotective activities [14]. T. polium possesses hypoglycemic [15], anti-inflammatory [16] and antinociceptive activities [17]. The therapeutic benefit of medicinal plants is often attributed to their antioxidant properties [18].

Different groups of researchers have reported various pharmacological activities of T. stocksianum like cytotoxic and anthelmintic [19]. Gul Rahim et al. have reported different folkloric uses of this plant from Pakistan [20].

Looking to the pharmacological potential of T. stocksianum we designed a research project to evaluate the crude methanolic extract of $T$. stocksianum for antioxidant, total phenolic contents and antinociceptive potential.

\section{Methods}

\section{Plant material}

Whole plant of T. stocksianum (TS) has been collected from Marghuzar valley of District Swat Khyber Pakhtunkhwa (KPK), Pakistan in the month of May 2012. The plant was authenticated by Dr. Nasrullah in the Department of Botany, University of Malakand, Pakistan. A voucher specimen (H.UOM.BG.199) of the plant was deposited in the University Herbarium for future reference.

\section{Preparation of plant extract}

The plant was air dried under shade, cut into small pieces and then pulverized to coarse powder. About one kilogram of the powdered plant material was macerated with methanol (80\%) for two days. The methanolic extract was concentrated at reduced pressure at $45^{\circ} \mathrm{C}$ temperature using rotary evaporator. The concentrated methanolic extract was stored in glass container in refrigerator for future use. The same procedure was repeated for the aerial parts and roots separately according to the design of our experimental procedure.

\section{Experimental animal}

Swiss albino mice of either sex, same age and 18-22 g weight were used in the present study. All the animals were housed in appropriate cages at standard controlled laboratory condition $\left(23^{\circ} \mathrm{C}, 12 \mathrm{~h}\right.$ light/dark cycle). Water and food were easily available to all experimental animals during acclimatization period. Food was withdrawn from all animals $18 \mathrm{hrs}$ before starting the experiment. The animals were randomly divided into five groups $(n=6)$. This study was approved by the ethical committee of Department of Pharmacy, University of Malakand according to animals Bye-Laws 2008 (Scientific procedure Issue-1).

\section{Chemicals and drugs}

All chemicals used in this study were of analytical grade purchased from Merck, Pakistan and Tramadol ${ }^{\mathrm{R}}$ was obtained from Searle Pakistan Ltd.

\section{Statistics and calculations}

The results obtained were expressed as mean \pm SEM (Standard error of mean) and Standard deviation (SD). One-way ANOVA followed by multiple comparison Dunnet test was applied for comparison of the test group 
with control. Differences with $P \leq 0.05$ were considered significant.

\section{Acute toxicity}

Acute toxicity test was conducted for METS. Four groups of Swiss albino mice of either sex $(n=6)$ were treated with various test doses, i.e. 250,500 and $1000 \mathrm{mg} / \mathrm{kg}$ intra peritoneal. The control group received 1\% tween-80 $(10 \mathrm{ml} / \mathrm{kg})$. Animals were constantly observed for any gross effect for initial $4 \mathrm{~h}$ and then the number of dead animals were recorded after $24 \mathrm{~h}$ [21].

\section{Phytochemical composition}

Phytochemical screening of the METS was carried out using standard procedures [22,23].

\section{Antioxidant potential}

\section{$D P P H$ radical scavenging potential}

DPPH (1,1-diphenyl-2-picryl-hydrazyl) is a stable free radical most commonly used for the evaluation of radical scavenging potential of extract/fractions of phytomedicine. Procedure reported by Blois and Yildirim was followed with slight modifications [24,25]. DPPH radical solution was prepared in methanol $(24 \mathrm{mg} / 100 \mathrm{ml})$ and $1 \mathrm{ml}$ of this solution was added to $1 \mathrm{ml}$ of methanolic solution of sample containing 20,40,60,80 and $100 \mu \mathrm{g}$ of the extract respectively. Methanol was used as negative control while Gallic acid, Quercetin and Ascorbic acid served as positive controls. The samples and control solutions were incubated in dark for $30 \mathrm{~min}$ at controlled temperature $\left(20-25^{\circ} \mathrm{C}\right)$. After incubation bleaching of the purple coloured methanolic solution of DPPH was observed. Absorbance of samples, control and standard were measured at $517 \mathrm{~nm}$. Percent radical scavenging activities (\%RSA) by DPPH free radical was calculated as follow.

$$
\% \text { RSA }=\frac{\text { Control absorbance-Sample absorbance }}{\text { Control absorbance }} \times 100
$$

The test of each sample was performed in triplicate and the results were expressed as mean values \pm standard deviations. Inhibitory concentration $\left(\mathrm{IC}_{50}\right)$ was calculated.

\section{Determination of total phenolic contents}

The antioxidant activity of medicinal plants is mostly due to the presence of phenol group (s) containing phytochemicals [26]. Total phenolic contents were estimated according to the procedure reported by Singleton et al. [27]. Calculated quantity of the methanolic extract was dissolved in methanol in order to get $500 \mu$ g concentrations. To $1 \mathrm{ml}$ of this solution $45 \mathrm{ml}$ of distilled water and $1 \mathrm{ml}$ of Folin-Ciocalteu Reagent (FCR) was mixed in a volumetric flask. Then after brief incubation $(3 \mathrm{~min}) 3 \mathrm{ml}$ of $\mathrm{Na}_{2} \mathrm{CO}_{3}(20 \%)$ solution was added to the mixture to make a final volume $50 \mathrm{ml}$. Afterwards, mixture was gently shacked for $2 \mathrm{~h}$ at controlled temperature $\left(20-30^{\circ} \mathrm{C}\right)$ and absorbance was taken at $760 \mathrm{~nm}$. Assay was performed in triplicate. The results were expressed as milligrams of gallic acid equivalent gram of dry weight ( $\mathrm{mg} \mathrm{GAE} / \mathrm{g} \mathrm{dw}$ ) and were calculated from the standard curve, using the following formula;

$$
\mathrm{A}=1156 \mathrm{C}+0189
$$

Where " $\mathrm{A}$ " is the absorbance of standard and sample and " $\mathrm{C}$ " is the Gallic acid equivalent $(\mathrm{mg} / \mathrm{g})$.

\section{Antinociceptive activity \\ Acetic acid induced writhing test}

In this study five groups $(n=6)$ were selected. The test groups received METS at a dose of 50, 100 and 200 (mg/kg, b.w, i.p) respectively. Control group was treated with $1 \%$ Tween 80 solution $(10 \mathrm{ml} / \mathrm{kg}$, b.w, i.p). Standard group received acetylsalicylic acid (100 mg/kg, b.w, s.c). All the groups were treated with test sample $(10 \mathrm{ml} / \mathrm{kg}$, $0.6 \%$, i.p) after $30 \mathrm{~min}$ of writhes induction. The number of abdominal writhes was counted for $20 \mathrm{~min}$ after 5 min of acetic acid administration. Percent inhibition was calculated by comparing the results of METS with the control group [28].

\section{Formalin induced paw licking test}

All mice were transferred to the observation chamber $10 \mathrm{~min}$ before the experiment for acclimatization to the new environment. Mice were divided into five groups $(n=6)$. Control group was treated with $1 \%$ Tween 80 solution (10 ml $/ \mathrm{kg}$, i.p). Test groups received METS 50, 100 and $200 \mathrm{mg} / \mathrm{kg}$ (i.p). Standard group was treated with acetylsalicylic acid $(100 \mathrm{mg} / \mathrm{kg}$, s.c). After $30 \mathrm{~min}$ of the drug administration, pain was induced in all mice by injecting $1 \%$ formalin solution $(20 \mu \mathrm{l})$ into the right hind paw through intraplantar route. Formalin (1\%) solution was prepared by diluting commercial formalin solution (10\%) with normal saline. The total number of licking the injected paw were observed during 0-5 min (Neurogenic, initial phase) and 20-30 min (Inflammatory, late phase) after formalin injection. Special measures were taken in order to avoid any possible disturbance during experiments that may affect the animal's response.

\section{Tail immersion test}

Five groups of six mice $(n=6)$ in each were selected for this study. Group 1 (control) received Tween 80 (1\%, $10 \mathrm{ml} / \mathrm{kg}$, b.w, i.p), group 2, 3 and 4 were treated with 50 , 100 and $200 \mathrm{mg} / \mathrm{kg}$, b.w, i.p METS respectively. Group 5 was treated with standard drug $\mathrm{Tramadol}^{\mathrm{R}}(30 \mathrm{mg} / \mathrm{kg})$. Pain reactions were induced by dipping the animal's tail $(2-5 \mathrm{~cm})$ in a pot of water maintained at $54 \pm 0.5^{\circ} \mathrm{C}$. The reaction time (in seconds) is the time taken by the animal 
Table 1 Comparison of \%RSA, TPC and IC 50 values of MAPETS and MRETS with Quercetin (Q) Values are expressed as the mean $\pm S D$

\begin{tabular}{|c|c|c|c|c|c|c|c|}
\hline \multicolumn{2}{|l|}{ TEST Solutions } & \multicolumn{4}{|c|}{ Comparison of \%RSA (Con $\mu \mathrm{g} / \mathrm{ml}$ ) } & \multirow{2}{*}{$\begin{array}{l}\text { TPC } \\
(\mathrm{mg} \text { GAE/g dw) }\end{array}$} & \multirow{2}{*}{$\begin{array}{l}\mathrm{IC}_{50} \\
\text { (Con } \mu \mathrm{g} / \mathrm{ml})\end{array}$} \\
\hline Sample/standard & 20 & 40 & 60 & 80 & 100 & & \\
\hline MAPETS & $82.58 \pm 0.93^{* * *}$ & $85.68 \pm 0.57^{* * *}$ & $87.58 \pm 0.60^{* * *}$ & $89.16 \pm 1.36^{* * *}$ & $91.6 \pm 0.90^{* * *}$ & $115.55 \pm 0.74$ & 12.5 \\
\hline MRETS & $46.55 \pm 1.11^{* * *}$ & $59.91 \pm 019^{* * *}$ & $68.51 \pm 0.60^{* * *}$ & $77.69 \pm 0.86^{* * *}$ & $86.3 \pm 0.4^{* * *} 6$ & $104.9 \pm 2.16$ & 24.5 \\
\hline Q & $94.95 \pm 0.86$ & $95.35 \pm 0.57$ & $96.48 \pm 0.53$ & $97.55 \pm 0.58$ & $98.2 \pm 0.81$ & $\longrightarrow$ & 10.2 \\
\hline
\end{tabular}

Results of multiple comparison Dunnetts test in one-way ANOVA; Groups significantly different ${ }^{* * *} \mathrm{p} \leq 0.001$ when compared to positive control group. ${ }^{* * *} \mathrm{p} \leq 0.001$, ** $\mathrm{p} \leq 0.01$ and ${ }^{*} \mathrm{p} \leq 0.05$ vs. control group $(n=6)$

to withdraw the tail from worm water. The reaction time was noted after $30 \mathrm{~min}$ of the test drug administration. In order to avoid tissue damage a 30 seconds cut-off time was maintained at $54 \pm 0.5^{\circ} \mathrm{C}$. The reaction time was observed at 0, 30, 60, 90 and $120 \mathrm{~min}$ after drug administration [29]. Naloxone was administered in a dose of $0.5 \mathrm{mg} / \mathrm{kg}$ body weight to observe whether the analgesia is antagonized or not.

\section{Results}

Acute toxicity

In this experiment METS was found safe at different test doses (250, 500 and $1000 \mathrm{mg} / \mathrm{kg}$ b.w, i.p). All the test animals were found normal. There were no signs of convulsions and any other gross effect during $24 \mathrm{~h}$ test time, which indicates low toxicity profile of METS.

\section{Phytochemical composition}

Preliminary phytochemical screening of METS indicated the presence of various classes of secondary metabolites like flavonoids, tannins, saponins, anthraquinones, steroids, phlobatannins, terpenoids, glycosides and reducing sugars.

\section{Antioxidant potential \\ $D P P H$ radical scavenging potential}

A concentration dependent free radical scavenging effect was observed with methanolic extract. The antioxidant activity of five different concentrations $(20,40,60,80$ and $100 \mu \mathrm{g} /$ ) was $82.43 \%, 85.93 \%, 87.38 \%, 89.38 \%$ and $91.72 \%$ respectively with $\mathrm{IC}_{50}$ value of $12.5 \mu \mathrm{g} / \mathrm{ml}$.

Values are expressed as the mean $\pm \mathrm{S} \mathrm{D}$. (mg GAE/g dw); milligrams of galic acid equivalent per gram of dry weight of plant material.

MRETS also exhibited a concentration depended radical scavenging effect. Different concentrations 100, $80,60,40$, and $20 \mu \mathrm{g} / \mathrm{ml}$ have shown $86.19 \%, 77.89 \%$, $68.54 \%, 59.96 \%$ and $46.66 \%$ radical scavenging activity respectively with $\mathrm{IC}_{50}$ value $24.5 \mu \mathrm{g} / \mathrm{ml}$. The \%RSA value of the extract was also compared with that of Quercetin (Table 1).

\section{Total phenolic contents}

Table 1 shows that crude methanolic extract of the aerial parts was composed of high quantity of total phenolic contents as compared to the root extract i.e. $115.32 \mathrm{mg}$ and $105.41 \mathrm{mg}$ of gallic acid equivalent per gram (GAE/g) of dry material respectively. The difference in the phenolic contents may be due to the presence of essential oils in the aerial parts of the plant.

\section{Acetic acid induced writhing test}

The antinociceptive potential of different doses of the METS are shown in Table 2. In control group maximum number of abdominal writhes during 20 min test period was $60.166 \pm 4.167$. The test groups treated with different concentrations of METS (50, 100 and $150 \mathrm{mg} / \mathrm{kg} \mathrm{b.w),}$ produced a significant $(p<0.001)$ and a dose dependent inhibition of abdominal writhes when compared to control group. Maximum writhes inhibition (83.103\%) was noted at highest concentration $(150 \mathrm{mg} / \mathrm{kg})$. The standard drug (Acetylsalicylic acid, $100 \mathrm{mg} / \mathrm{kg}$ ) produced $74.793 \%$ writhes inhibition when compared to control group.

\section{Formalin induced paw licking}

MAPETS showed a dose dependent relationship in Phase I (neurogenic) as well as in Phase II (inflammatory) of formalin induced pain. In Phase I the extract produced a significant inhibition $(19.787 \%, p<0.05)$ at a dose of $150 \mathrm{mg} / \mathrm{kg}$ compared to control. In phase II the extract produced a significant inhibition $(50.275 \%, p<0.001)$,

Table 2 Antinociceptive effect of METS 50, 100 and $150 \mathrm{mg} / \mathrm{kg}$ in acetic acid induced abdominal writhing test

\begin{tabular}{llll}
\hline Samples & Dose & Number of writhes & \% inhibition \\
\hline $1 \%$ tween 80 & $10 \mathrm{ml} / \mathrm{kg}$ & $60.166 \pm 4.167$ & - \\
METS & $50 \mathrm{mg} / \mathrm{kg}$ & $30.166 \pm 4.070$ & $49.862^{* * *}$ \\
& $100 \mathrm{mg} / \mathrm{kg}$ & $22.833 \pm 2.786$ & $62.05^{* * *}$ \\
& $150 \mathrm{mg} / \mathrm{kg}$ & $10.166 \pm 2.786$ & $83.103^{* * *}$ \\
Acetylsalicylic acid & $100 \mathrm{mg} / \mathrm{kg}$ & $15.166 \pm 3.656$ & 74.793 \\
\hline
\end{tabular}

Results of multiple comparison Dunnetts test in one-way ANOVA; Groups significantly different ${ }^{* * *} \mathrm{p} \leq 0.001$ when compared to positive control group. Percent inhibition was calculated in comparison to control group. $F=187.523$, d.f. $=29$. ED50 for analgesic effect of METS was $50.68 \mathrm{mg} / \mathrm{kg}$ (b.w). ${ }^{* * *} \mathrm{p} \leq 0.001$, ${ }^{* *} p \leq 0.01$ and ${ }^{*} p \leq 0.05$ vs. control group $(n=6)$. 
Table 3 Effect of MAPETS 50, 100 and $150 \mathrm{mg} / \mathrm{kg}$ in Formalin induced paw licking

\begin{tabular}{|c|c|c|c|c|c|}
\hline \multirow[t]{2}{*}{ Samples } & \multirow[t]{2}{*}{ Dose } & \multicolumn{2}{|c|}{ Phase I } & \multicolumn{2}{|c|}{ Phase II } \\
\hline & & No of paw licking & $\%$ inhibition & No of paw licking & $\%$ inhibition \\
\hline 1\% Tween 80 & 10 ml/kg & $47.166 \pm 2.85$ & 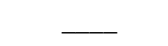 & $30.166 \pm 1.70$ & 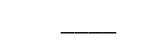 \\
\hline \multirow[t]{3}{*}{ MAPETS } & 50 mg/kg & $42.666 \pm 1.87$ & 09.542 & $15.166 \pm 1.74^{* * *}$ & 50.275 \\
\hline & $100 \mathrm{mg} / \mathrm{kg}$ & $39.166 \pm 3.00$ & 16.961 & $6.333 \pm 0.98^{* *}$ & 77.348 \\
\hline & $150 \mathrm{mg} / \mathrm{kg}$ & $37.833 \pm 2.64^{*}$ & 19.787 & $5.833 \pm 0.90^{*}$ & 80.663 \\
\hline Acetylsalicylic acid & $100 \mathrm{mg} / \mathrm{kg}$ & $40.833 \pm 2.49$ & $\ldots$ & $2.833 \pm 0.60$ & 82.872 \\
\hline
\end{tabular}

Values expressed as mean \pm SEM. Percent inhibition was calculated in comparison to the control group. ${ }^{* *} p \leq 0.001,{ }^{* *} p \leq 0.01$ and ${ }^{*} p \leq 0.05$ vs. control group ( $n=6$ ).

$(77.348 \%, p<0.01),(80.663 \%, p<0.05)$ at a dose of 50,100 and $150 \mathrm{mg} / \mathrm{kg}$ as shown in Table 3.

\section{Tail immersion test}

In this procedure different concentrations (50, 100 and $150 \mathrm{mg} / \mathrm{kg}$ ) of METS were tested in various groups of mice. The reaction time of animals against heat stimulus was recorded. The analgesic effect of METS was non significant in all the test doses. The highest effect $(67.58 \%)$ of the extract was noted at $60 \mathrm{~min}$ at a dose of $150 \mathrm{mg} / \mathrm{kg}$ compared to control group. Moreover, the analgesic effect of Tramadol $^{\mathrm{R}}(30 \mathrm{mg} / \mathrm{kg})$ and METS $(150 \mathrm{mg} / \mathrm{kg}$ ) was antagonized by naloxone as shown in Table 4

\section{Discussion}

Teucrium genus has been extensively studied and proved to be a useful medicinal herb. A diverse array of pharmacological activities have been reported from this genus. In our previous work, we reported the chemical composition and antinociceptive potential of the essential oil of T. stocksianum [30]. In the current study we investigated antioxidant, TPC and antinociceptive potential of the crude methanolic extract of T. stocksianum.

Geographical location and temperature variations are very important for production of secondary metabolites which actually possess therapeutic properties
(M.A. Couceiro, A. Cristina Figueiredo). We are reporting data of Teucrium stocksianum collected in the cold hilly area of North-West of Pakistan i,e Swat while Radhakrishnan et al. have reported data from plant collected from the hot environment of UAE (Radhakrishnan). Our results are different from results reported by the other study.

Living organisms during normal metabolism produce reactive oxygen species (ROS) which are responsible for a number of diseases such as rheumatic joint inflammation, Alzheimer's, Parkinson's, diabetes, hypertension, atherosclerosis and oxidative stress [31]. It is well documented that flavonoids possess significant antioxidant potential due the presence of phenolic hydroxyl groups [26]. Our results show that the extract of the aerial parts of TS possesses strong antioxidant potential and high quantity of TPC (91.66\%, $115.55 \mathrm{mg} \mathrm{GAE} / \mathrm{g} \mathrm{dw}$ ) as compared to roots (86.34\%, $104.9 \mathrm{mg} \mathrm{GAE} / \mathrm{g} \mathrm{dw}$ ) which might be due to the presence of high quantity of total phenolic contents and flavonoids. Moreover phytochemical screening of METS has also shown the presence of flavonoids. Many studies are available which relate analgesic, anti-inflammatory and antioxidant activities with flavonoids by interacting with prostaglandins and superoxides [32].

Acetic acid causes abdominal constrictions by releasing certain endogenous chemical substances like histamine, serotonin, bradykinin and different prostaglandins which stimulate the pain sensitive neurons. These neurons are

Table 4 Effect of METS 50, 100 and $150 \mathrm{mg} / \mathrm{kg}$ in Tail immersion test

\begin{tabular}{|c|c|c|c|c|c|c|}
\hline \multirow[t]{2}{*}{ Samples } & \multirow[t]{2}{*}{ Dose $\mathrm{mg} / \mathrm{kg}$} & \multicolumn{5}{|c|}{ Tail withdrawing time in sec } \\
\hline & & $0 \mathrm{~min}$ & $30 \mathrm{~min}$ & $60 \mathrm{~min}$ & $90 \mathrm{~min}$ & $120 \mathrm{~min}$ \\
\hline $1 \%$ tween 80 & $10 \mathrm{ml} / \mathrm{kg}$ & $3.45 \pm 0.26$ & $3.48 \pm 0.19^{\text {ns }}$ & $3.27 \pm 0.032^{\text {ns }}$ & $3.48 \pm 0.20^{\mathrm{ns}}$ & $3.57 \pm 0.19$ \\
\hline \multirow[t]{3}{*}{ METS } & $50 \mathrm{mg} / \mathrm{kg}$ & $3.48 \pm 0.19$ & $3.57 \pm 0.19^{n s}$ & $4.11 \pm 0.12^{\mathrm{ns}}$ & $4.16 \pm 0.12^{\mathrm{ns}}$ & $4.09 \pm 0.11^{\mathrm{ns}}$ \\
\hline & 100 mg/kg & $3.53 \pm 0.18$ & $4.25 \pm 0.04^{\mathrm{ns}}$ & $4.49 \pm 0.13^{\mathrm{ns}}$ & $4.39 \pm 0.08^{n s}$ & $4.29 \pm 0.04^{\mathrm{ns}}$ \\
\hline & $150 \mathrm{mg} / \mathrm{kg}$ & $3.57 \pm 0.19$ & $4.82 \pm 0.04^{\mathrm{ns}}$ & $5.48 \pm 0.02^{\mathrm{ns}}$ & $5.27 \pm 0.05^{\mathrm{ns}}$ & $5.18 \pm 0.06^{\mathrm{ns}}$ \\
\hline Tramadol $^{R}$ & $30 \mathrm{mg} / \mathrm{kg}$ & $3.48 \pm 0.20$ & $4.99 \pm 0.33$ & $5.69 \pm 0.02$ & $5.49 \pm 0.06^{\mathrm{ns}}$ & $5.38 \pm 0.05^{\mathrm{ns}}$ \\
\hline \multicolumn{7}{|c|}{ Antinociceptive effect of METS and Tramadol ${ }^{R}$ antagonized by Naloxone } \\
\hline METS & $150 \mathrm{mg} / \mathrm{kg}$ & $3.52 \pm 0.02^{n s}$ & $2.64 \pm 0.01^{\mathrm{ns}}$ & $2.87 \pm 0.02^{\mathrm{ns}}$ & $2.73 \pm 0.01^{\mathrm{ns}}$ & $2.69 \pm 0.01^{\mathrm{ns}}$ \\
\hline Tramadol $^{R}$ & $30 \mathrm{mg} / \mathrm{kg}$ & $3.50 \pm 0.02$ & $2.35 \pm 0.02$ & $2.69 \pm 0.01$ & $2.75 \pm 0.02$ & $2.65 \pm 0.02$ \\
\hline
\end{tabular}

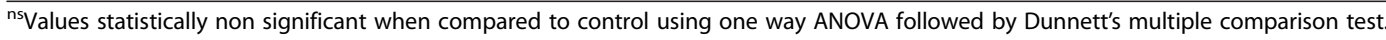


sensitive to pain relieving drugs like non steroidal antiinflammatory drugs (NSAIDs) and narcotics [33,34]. In acetic acid induced writhing test, METS exhibited significant results. At 50, 100 and $150 \mathrm{mg} / \mathrm{kg}$ doses the abdominal constrictions were reduced to $49.86 \%, 62.05 \%$ and $83.10 \%(p<0.001)$ respectively as shown in Table 2 . It has been found that METS possesses strong antinociceptive potential as compared to the methanolic extract of T. polium $(65.44 \%, 225 \mathrm{mg} / \mathrm{kg})$ and aqueous extract of T. chamaedrys $(76.4 \%, 200 \mathrm{mg} / \mathrm{kg})$. It has been reported that the essential oil of TS possesses significant $93.97 \%$ $(p<0.001)$ antinociceptive activity at a very low dose $(80 \mathrm{mg} / \mathrm{kg})$ [30] as compared to the methanolic extract of the same plant.

It has been postulated by Collier et al. that acetic acid causes an indirect stimulation of the nociceptive neurons sensitive to the opioids and NSAIDs by inducing the releases of various endogenous mediators [35]. Based on our current findings, the antinociceptive activity of METS is possibly due to inhibition of response or release of endogenous noxious mediators that causes activation and sensitization of peripheral nociceptors. Therefore, the results of acetic acid induced abdominal constrictions are not sufficient to understand the exact antinociceptive mechanism, that the effect produced by the extract was mediated by central or peripheral pathways [36].

In order to understand the mechanism of analgesia, formalin induced pain model was used [37]. This is a biphasic antinociceptive procedure. The centrally acting drug inhibits both phase I and phase II while the peripherally acting drugs can only inhibit phase II of formalin induced pain model [38]. In this study it was observed that the METS significantly decreased the number of paw licking in both phases of formalin induced pain, indicating that the extract caused the analgesic effect through central mechanism. It was found that the extract at a dose of $150 \mathrm{mg} / \mathrm{kg}$ was highly effective producing $80.663 \%$ inhibition in phase II, suggesting a strong peripheral effect (Table 4).

Tail immersion test is a specific central procedure. This test has shown that mu $(\mu)$ opioids receptors were involved in antinociceptive effect rather than kappa (k) or delta receptors [39]. Literature shows that descending inhibition pathways and opioidergic system involving serotonergic and noradrenergic systems play a vital role in pain regulation at spinal and supraspinal level $[40,41]$. The METS has significantly increased the latency time (\%) at a dose of $150 \mathrm{mg} / \mathrm{kg}$. Maximum effect for all test doses of METS was recorded after 60 min which persists upto $120 \mathrm{~min}$. Naloxone an opioid receptor antagonist, when applied reversed profoundly the analgesic effect of METS after $30 \mathrm{~min}$ of administration. This shows that the antinociceptive potential of the extract is due to activation of the opioid receptors.
In conclusion, the methanolic extract of $T$. stocksianum possesses antioxidant and antinociceptive potentials. According to our findings both peripheral and central pathways are involved in relief of pain.

\section{Competing interests}

The authors have declared that they have no conflict of interest.

\section{Authors' contributions}

SMMS performed all the experiments, FU and SMHS did literature survey, AS, FU and SMMS prepared the manuscript. Before submission all the authors have checked and approved the final manuscript.

\section{Acknowledgments}

The authors are thankful to the Professor Dr. Muhammad Rasul Jan, Vice Chancellor University of Malakand, Pakistan for financial support. We are also thankful to Dr. Nasrullah, Assistant Professor at Department of Botany of the same University for the identification of the plant.

\section{Author details}

${ }^{1}$ Department of Pharmacy, University of Malakand, Chakdara Dir, KPK, Paksitan. ${ }^{2}$ Department of Pharmacy, Sarhad University of Science and Information Technology, Peshawar, KPK, Pakistan.

Received: 16 February 2013 Accepted: 20 May 2014

Published: 3 June 2014

\section{References}

1. Baker JT, Borris RP, Carte B, Cordell GA, Soejarto DD, Cragg GM, Gupta MP, Iwu MM, Madulid DR, Tyler VE: Natural product drug discovery and development: new perspectives on international collaboration. J Nat Prod 1995, 58(9):1325-1357.

2. WHO: WHO issues guidelines for herbal medicines. Bull World Health Organ 2004, 82(3):238.

3. Halliwell B: Biochemistry of oxidative stress. Biochem Soc Trans 2007, 35(Pt 5):1147-1150.

4. Devasagayam T, Tilak J, Boloor K, Sane KS, Ghaskadbi SS, Lele R: Free radicals and antioxidants in human health: current status and future prospects. J Assoc Physicians India 2004, 52:794-804.

5. Couladis M, Tzakou O, Verykokidou E, Harvala C: Screening of some Greek aromatic plants for antioxidant activity. Phytother Res 2003, 17(2):194-195.

6. Merskey H, Bogduk N: Classification of chronic pain. Seattle: IASP; 1994.

7. Damaj Ml, Glassco W, Aceto MD, Martin BR: Antinociceptive and pharmacological effects of metanicotine, a selective nicotinic agonist. J Pharmacol Exp Ther 1999, 291(1):390-398.

8. Farshchi A, Ghiasi G, Khatabi PM, Farzaee H, Niayesh A: Antinociceptive effect of promethazine in mice. Iran J Basic Med Sci 2009, 12(3-4):140-145.

9. Tomás-Barberán FA, Gil MI: Advances in Labiatae science. The Royal Botanic Gardens Kew; 1992:299-305.

10. Naghibi F, Mosaddegh M, Motamed SM, Ghorbani A: Labiatae family in folk medicine in Iran: from ethnobotany to pharmacology. Iran J Pharm Res 2005, 2:63-79.

11. Khoshnood-Mansoorkhani MJ, Moein MR, Oveisi N: Anticonvulsant activity of Teucrium polium against seizure Induced by PTZ and MES in mice. Iran J Pharm Res 2010, 9(4):395-401.

12. Ricci D, Fraternale D, Giamperi L, Bucchini A, Epifano F, Burini G, Curini M: Chemical composition, antimicrobial and antioxidant activity of the essential oil of Teucrium marum (Lamiaceae). J Ethnopharmacol 2005, 98(1-2):195-200.

13. Ahmad B, Mukarram Shah SM, Khan H, Hassan Shah SM: Enzyme inhibition activities of Teucrium royleanum. J Enzyme Inhib Med Chem 2007, 22(6):730-732

14. Panovska TK, Kulevanova S, Gjorgoski I, Bogdanova M, Petrushevska G: Hepatoprotective effect of the ethyl acetate extract of Teucrium polium L. against carbontetrachloride-induced hepatic injury in rats. Acta Pharm 2007, 57(2):241-248.

15. Gharaibeh MN, Elayan HH, Salhab AS: Hypoglycemic effects of Teucrium polium. J Ethnopharmacol 1988, 24(1):93-99.

16. Tariq M, Ageel AM, Al-Yahya MA, Mossa JS, Al-Said MS: Anti-inflammatory activity of Teucrium polium. Int J Tissue React 1989, 11(4):185-188. 
17. Abdollahi M, Karimpour H, Monsef-Esfehani HR: Antinociceptive effects of Teucrium polium $L$ total extract and essential oil in mouse writhing test. Pharmacol Res 2003, 48(1):31-35.

18. Rice-Evans C: Flavonoids and isoflavones: absorption, metabolism, and bioactivity. Free Radic Biol Med 2004, 36(7):827-828.

19. Ali N, Shah SW, Shah I, Ahmed G, Ghias M, Khan I: Cytotoxic and anthelmintic potential of crude saponins isolated from Achillea Wilhelmsii C. Koch and Teucrium Stocksianum boiss. BMC Complement Altern Med 2011, 11:106.

20. Rahim G, Qureshi R, Gulfraz M, Arshad M, Rahim S: Preliminary phytochemical screening and ethnomedicinal uses of Teucrium stocksianum from Malakand division. J Med Plants Res 2012, 6(5):704-707.

21. Khan H, Saeed M, Gilani AU, Khan MA, Dar A, Khan I: The antinociceptive activity of Polygonatum verticillatum rhizomes in pain models. J Ethnopharmacol 2010, 127(2):521-527.

22. Harborne JB: Methods of plant analysis. In Phytochemical methods. 3rd edition. London: Chapman and Hall LTD; 1973:135-203.

23. Sofowora A: Medicinal plants and traditional medicine in African. John Wiley and sons LTD; 1982:150-153.

24. Yildirm A, Mavi A, Kara AA: Antioxidant and antimicrobial activities of Polygonum cognatum Meissn extracts. J Sci Food Agric 2003, 83:64-69.

25. Blois M: Antioxidant determinations by the use of a stable free radical. Nature 1958, 181:1199-1200.

26. Cao G, Sofic E, Prior RL: Antioxidant and prooxidant behavior of flavonoids: structure-activity relationships. Free Radic Biol Med 1997 22(5):749-760.

27. Singleton $\mathrm{VL}$, Orthofer R, Lamuela-Raventos RM: Analysis of total phenols and other oxidation substrates and antioxidants by means of Folin Ciocalteu reagent. Methods Enzymol 1999, 299(152-178):152.

28. Parimalakrishnan S, Dey A, Smith A, Manavalan R: Evaluation of anti-inflammatory, antinociceptive and antipyretic effects of methanolic extract of Cleome chelidonii. Int J Biol Chem Sci 2007, 1:223-228.

29. Singh S, Majumdar DK, Rehan HM: Evaluation of anti-inflammatory potential of fixed oil of Ocimum sanctum (Holybasil) and its possible mechanism of action. J Ethnopharmacol 1996, 54(1):19-26.

30. Shah SM, Ullah F, Zahoor M, Sadiq A: Analysis of chemical constituents and antinociceptive potential of essential oil of Teucrium Stocksianum bioss collected from the North West of Pakistan. BMC Complement Altern Med 2012, 12:244.

31. Halliwell B, Gutteridge JM: Oxygen toxicity, oxygen radicals, transition metals and disease. Biochem J 1984, 219(1):1-14.

32. Narayana KR, Reddy MS, Chaluvadi MR, Krishna DR: Bioflavonoids classification, pharmacological, biochemical effects and therapeutic potential. Ind J Pharmacol 2001, 33:2-16.

33. Taesotikul T, Panthong A, Kanjanapothi D, Verpoorte R, Scheffer Jj: Anti-inflammatory, antipyretic and antinociceptive activities of Tabernaemontana pandacaqui Poir. J Ethnopharmacol 2003, 84(1):31-35.

34. Nguemfo EL, Dimo T, Azebaze AG, Asongalem EA, Alaoui K, Dongmo AB, Cherrah Y, Kamtchouing P: Anti-inflammatory and anti-nociceptive activities of the stem bark extracts from Allanblackia monticola STANER L.C. (Guttiferae). J Ethnopharmacol 2007, 114(3):417-424.

35. Collier HO, Dinneen LC, Johnson CA, Schneider C: The abdominal constriction response and its suppression by analgesic drugs in the mouse. Br J Pharmacol Chemother 1968, 32(2):295-310.

36. Couto VM, Vilela FC, Dias DF, Dos Santos MH, Soncini R, Nascimento CG, Giusti-Paiva A: Antinociceptive effect of extract of Emilia sonchifolia in mice. J Ethnopharmacol 2011, 134(2):348-353.

37. Tjolsen A, Berge OG, Hunskaar S, Rosland JH, Hole K: The formalin test: an evaluation of the method. Pain 1992, 51(1):5-17.

38. Santos AR, Filho VC, Niero R, Viana AM, Moreno FN, Campos MM, Yunes RA, Calixto JB: Analgesic effects of callus culture extracts from selected species of Phyllanthus in mice. J Pharm Pharmacol 1994, 46(9):755-759.

39. Schmauss C, Yaksh TL: In vivo studies on spinal opiate receptor systems mediating antinociception. II. Pharmacological profiles suggesting a differential association of $\mathrm{mu}$, delta and kappa receptors with visceral chemical and cutaneous thermal stimuli in the rat. J Pharmacol Exp Ther 1984, 228(1):1-12.
40. Pinardi G, Sierralta F, Miranda HF: Adrenergic mechanisms in antinociceptive effects of non steroidal anti-inflammatory drugs in acute thermal nociception in mice. Inflamm Res 2002, 51(5):219-222.

41. Bardin L, Lavarenne J, Eschalier A: Serotonin receptor subtypes involved in the spinal antinociceptive effect of 5-HT in rats. Pain 2000, 86(1-2):11-18.

doi:10.1186/1472-6882-14-181

Cite this article as: Shah et al:: Antioxidant, total phenolic contents and antinociceptive potential of Teucrium stocksianum methanolic extract in different animal models. BMC Complementary and Alternative Medicine 2014 14:181

\section{Submit your next manuscript to BioMed Central and take full advantage of:}

- Convenient online submission

- Thorough peer review

- No space constraints or color figure charges

- Immediate publication on acceptance

- Inclusion in PubMed, CAS, Scopus and Google Scholar

- Research which is freely available for redistribution 